\title{
ANALISIS PERAN KADER TERHADAP CAKUPAN IMUNISASI DASAR LENGKAP DI POSYANDU WILAYAH KERJA PUSKESMAS KERENG BANGKIRAI PALANGKA RAYA
}

\author{
The Career's Role Analyze On Complete Basic Immunization Coverage At Kereng \\ Bangkirai Posyandu, Working Area Of Kereng Bangkirai Health Centre, Palangka Raya
}

\author{
Septian Mugi Rahayu ' \\ Maria Adelheid Ensia ${ }^{2}$ \\ Evaririn $^{3}$
}

*123 STIKES Eka Harap, Palangka Raya, Kalimantan Tengah,

Indonesia

*email:

septianmugirahayu@gmail.com

\begin{abstract}
Abstrak
Cakupan imunisasi anak di negara- negara anggota WHO (World Health Organization) telah mencapai $90 \%$, diperkirakan $85 \%$ dari bayi diseluruh dunia telah mendapat imunisasi. Namun masih terdapat $19,3 \%$ juta bayi dan anak-anak belum sepenuhnya mendapatkan vaksinasi beresiko terkena penyakit PD3I. Di Kalimantan Tengah kasus PD3I yaitu penyakit tetanus neonatrum terdapat 2 kasusmeninggal dengan status tidak imunisasi, penyakit campak terdapat 569 kasus dengan 424 kasus status tidak imunisasi, penyakit difteri terdapat 2 kasus dengan status tidak imunisasi. Untuk Kota Palangka Raya kasus PD3l yaitu penyakit suspek campak 260 kasus dengan 197 kasus tidak imunisasi, penyakit difteri I kasus dengan status imunisasi, diwilayah Puskesmas Kereng Bangkirai terdapat 2 kasus suspek campak.Penelitian ini bertujuan mengetahui Hubungan Peran Kader Dengan Cakupan Imunisasi Dasar Lengkap Pada Bayi Usia 0-II Bulan di Posyandu Wilayah Kerja Puskesmas Kereng Bangkirai Kota Palangka Raya.Penelitian yang digunakan penelitian korelasional, rancangan penelitian cross sectional dengan teknik accidental sampling yang jumlah responden sebanyak 35. Hasil analisis Chi-Square, diperoleh nilai $0,003<(\alpha=0,05)$, maka $\mathrm{HI}$ diterima, hal tersebut terdapat hubungan antara peran kader dengan cakupan imunisasi dasar lengkap pada bayi usia 0-II bulan di Posyandu Wilayah Puskesmas Kereng Bangkirai Kota Palangka Raya. Dapat disimpulkan peran kader penting terhadap imunisasi dasar lengkap terutama dalam memberikan informasi dan motivasi tentang pentingnya imunisasi sehingga dapat meningkatkan derajat kesehatan dimasyarakat. Bagi tempat penelitian diharapkan dapat memberikan motivasi kepada orang tua untuk memperhatikan kelengkapan imunisasi pada bayinya dan memberikan penyuluhanpentingnya imunisasi.
\end{abstract}

Kata Kunci:

Peran Kader

Imunisasi Dasar

Keywords:

Role of Cadres

Basic Immunization

\begin{abstract}
The coverage of child immunization in WHO member countries (World Health Organization) has reached $90 \%$, it is estimated that $85 \%$ of babies worldwidehave been immunized. But there are still 19.3\% million babies and children who have not fully received vaccinations at risk of developing PD3I. In Central Kalimantan PD3I cases, namely tetanus neonatrum, there were 2 cases died with no immunization status, measles had 569 cases with 424 cases of non- immunization status, diphtheria had 2 cases with non-immunization status. For the City of Palangka Raya, the PD3I case is measles suspicion, 260 cases with 197 cases not immunized, diphtheria I case with immunization status, Kereng Bangkirai Community Health Center there are 2 cases of measles suspected. This study aims to determine the relationship of the role of cadres with complete basic immunization coverage in infants aged $0-1 /$ months at the Posyandu in Kereng Bangkirai Health Center, Palangka Raya City. The study used correlational research, the study design was cross sectional with accidental sampling technique, the number of respondents was 35. The results of Chi-Square analysis, obtained a valueof $0.003<(\alpha=0.05)$, thenHI was accepted, there was a relationship between the role of cadres with complete basic immunization coverage in infants aged 0-I I months at Posyanduin Kereng Bangkirai Health Center, Palangka Raya City . It can be concluded that the role of important cadres in complete basic immunization, especially in providing information and motivation about the importance of immunization so that it can improve health status in the community. For research sites, it is expected to provide motivation to parents to pay attention to the completeness of immunizations to their babies and provide information on the importance of immunization.conclusions. Abstract should not contain tables/images without including a citation. The use of abbreviations should be minimum except for units. Abstract does not have to be a translation from indonesian abstract word by word, but has the same content. Objectives and methodology are arranged in the form of past tense, while the results and conclusions in the form of simple present tense.
\end{abstract}




\section{PENDAHULUAN}

Imunisasi adalah pemberian kekebalan tubuh terhadap suatu penyakit dengan memasukkan sesuatu antibodi ke dalam tubuh agar tubuh tahan terhadap penyakit yang sedang mewabah atau berbahaya bagi seseorang. Imunisasi dasar adalah usaha memberi kekebalan pada bayi dan anak dengan memasukan vaksin kedalam tubuh agar tubuh membuat zat anti untuk mencegah terhadap penyakit tertentu (Marimbi, 20/4:36). Imunisasi diberikan oleh petugas kesehatan pada saat kegiatan Posyandu yang dibantu oleh kader kesehatan. Imunisasi juga diberikan pada pelayanan dalam Puskesmas dibantu oleh kader Posyandu setempat. Kader Posyandu adalah orang yang mempunyai tugas untuk melaksanakan program Posyandu termasuk didalamnya adalah imunisasi, kader Posyandu mempunyai peran penting dalam meningkatkan kelengkapan imunisasi bayi usia 0 -II bulan. Upaya menurunkan angka kesakitan, kematian, dan kecacatan akibat Penyakit yang Dapat Dicegah Dengan Imunisasi (PD3I), sangat ditentukan oleh cakupan imunisasi yang tinggi dan merata di semua desa/kelurahan yang dapat dinilai dari capaian Universal Child Immunization (UCI) desa. $\mathrm{UCl}$ adalah suatu kondisi dimana $80 \%$ bayi yang ada disuatu desa telah mendapatkan lima imunisasi dasar lengkap yang meliputi Hepatitis B I kali, BCG I kali, DPT-HB 3 kali, Polio 4 kali, dan Campak I kali (Kemenkes RI, 20I7:8). Pada kenyataannya saat ini yang terjadi dilapangan masih kurangnya kesadaran masyarakat untuk melakukan imunisasi, kurangnya informasi tentang imunisasi yang diberikan oleh tenaga kader atau tenaga kesehatan kepada masyarakat.

Cakupan imunisasi anak di negara- negara anggota WHO (World HealthOrganization) telah mencapai 90\%, dan diperkirakan $85 \%$ dari bayi diseluruh dunia telah mendapat imunisasi. Namun masih terdapat 19,3\% juta bayi dan anak- anak belum sepenuhnya mendapatkan vaksinasi dan tetap beresiko terkena penyakit yang dapat dicegah dengan imunisasi (Depkes RI, 20I3: 33).

Pada tahun 2015 cakupan imunisasi dasar lengkap di Indonesia hanya 86,5 \% dari target yang ditetapkan sebesar 91\% (Rikesdas, 2015:I19). Sedangkan persentase anak usia 12 - 23 bulan yang mendapatkan imunisasi Basillus CalmetteGeurin (BCG) sebesar 77,9\%, Polio sebesar 66,7\%, Diphteria, Pertusis, Tetanus, Hepatitis B (DPT-HB) sebesar 61,9\% dan campak sebesar 74,4\%. Persentase imunisasi lengkap di perkotaan lebih tinggi yaitu sebesar $59,1 \%$ daripada di pedesaan yang hanya $48,3 \%$ dan masih terdapat $17,7 \%$ anak 12-23 bulan di pedesaan yang tidak mendapat imunisasi sama sekali. Sedangkan pada tahun $2013 \mathrm{di}$ Indonesia target bayi di imunisasi adalah $95 \%$, sedangkan untuk imunisasi Polio I dapat dicapai 97,92 \%, Polio 2 sebesar 93,76\% sudah mencapai target Universal Child Immunization ( $\mathrm{UCl}$ ), sedangkan untuk Polio 3 sebesar $85,43 \%$, Polio 4 sebesar 87,5 I \% secara keseluruhan belum mencapai target $\mathrm{UCl}$. Menurut data Dinas Kesehatan Provinsi Kalimantan Tengah tahun 2017 untuk target imunisasi dasar lengkap yang telah ditetapkan secara nasional yaitu sebesar 91,5\%, sedangkan data capaian Kalimantan Tengah sebesar 85\%, untuk Kota Palangka Raya sebesar 90,4\%, sedangkan Puskesmas Kereng Bangkirai sebesar 66,4\% masih jauh dari target sebesar 91,5\%. Terdapat masih ada $33,6 \%$ yang belum mendapatkan imunisasi dasar lengkap. Hal tersebut masih jauh dari target, yang menunjukkan bahwa cakupan imunisasi tidak merata.

Beberapa alasan bayi tidak mendapatkan imunisasi lengkap yaitu karena alasan kurang informasi, motivasi dan situasi (Torik, 20/3:80). Alasan utama tidak imunisasi adalah takut anak panas, keluarga tidak mengijinkan, anak sering sakit, tidak tahu tempat imunisasi, tempat imunisasi jauh serta sibuk/repot (Rikesdas, 2013:195). Angka kematian bayi dan balita yang tinggi di Indonesia menyebabkan turunnya derajat kesehatan masyarakat, hal ini salah satunya 
disebabkan oleh tidak diberikan imunisasi dasar lengkap yang menyebabkan anak mudah terserang penyakit yang dapat dicegah dengan imunisasi karena tidak ada sistem pertahanan tubuh yang kuat dan akan mempengaruhi tumbuh kembang anak. Anak yang telah diberi imunisasi akan terlindungi dari beberapa penyakit menular yang termasuk dalam penyakit yang dapat dicegah dengan imunisasi antara lain Tuberculosis (TBC), difteri, tetanus, hepatitis B, pertusis, campak, rubella, polio, radang selaput otak dan radang paruparu yang dapat menimbulkan kecatatan atau kematian. Beberapa hal alasan rendahnya cakupan imunisasi yaitu ada masyarakat yang tidak mau anaknya diimunsisi, adanya penolakan dari orang tua karena takut anak panas, pengetahuan petugas yang masih rendah dan perankader Posyandu yang masih belum maksimal (Kiftiyah, 2017:43).

\section{METODOLOGI}

Pada penelitian ini menggunakan desaian penelitian cross sectional, dengan ini peneliti akan melakukan penelitian Hubungan Peran Kader Dengan Cakupan Imunisasi Dasar Lengkap Pada Bayi Usia 0 - II Bulan di Posyandu Wilayah Kerja Puskesmas Kereng Bangkirai Kota Palangka Raya. Sampel dalam penelitian ini orang tua yang mengantarkan bayi usia 9-I I bulan untuk imunisasi di Posyandu wilayah kerja Puskesmas Kereng Bangkirai Kota Palangka Raya berjumlah 35 sampel berdasarkan data yang memiliki KMS dan mendapatkan imunisasi. Uji statistik yang digunakan adalah uji Chi-square.

\section{HASIL DAN PEMBAHASAN}

Data demografi responden yang diperoleh oleh peneliti yaitu umur, usia anak responden, tingkat pendidikan dan pekerjaan. Data demografi tersebut akan dianalisis dan dihasilkan distribusi dan presentase dari setiap variabel. Analisa univariat atau univariate analysis adalah melakukan eksplorasi setiap variabel di dalam set data secara terpisah.

\section{Karakteristik Responden Berdasarkan Usia}

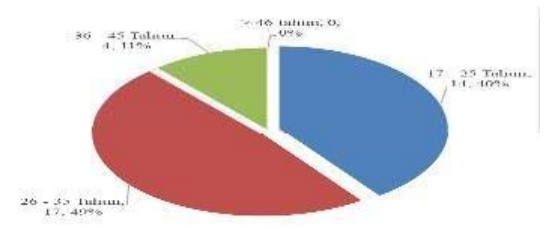

Berdasarkan diagram diatas, dari 35 responden terdapat 14 responden dengan usia 17-25 tahun (40\%), 17 responden dengan usia 26-35 tahun (49\%), 4 responden dengan usia 36-45 tahun ( $11 \%$ ) sedangkan usia lebih dari 46 tahun tidak ada (0\%). Hal ini menunjukan bahwa mayoritas responden yang datang ke Posyandu berusia 26-35 tahun.

\section{Karakteristik Responden Berdasarkan Tingkat Pendidikan}

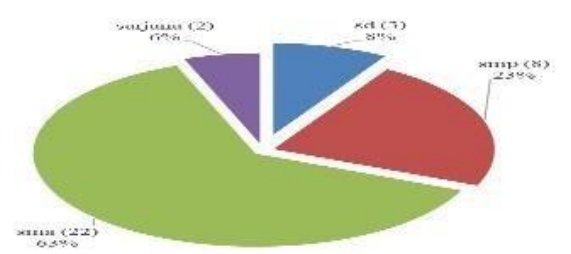

Berdasarkan diagram diatas, dari 35 responden terdapat 3 responden dengan tingkat pendidikan SD (8\%), 8 responden dengan tingkat pendidikan SMP (23\%), 22 responden dengan tingkat pendidikan SMA (63\%) dan 2 responden dengan tingkat pendidikan sarjana (6\%). Hal ini menunjukan bahwa mayoritas responden dengan pendidikan SMA.

\section{Karakteristik Responden Berdasarkan Usia Anak}

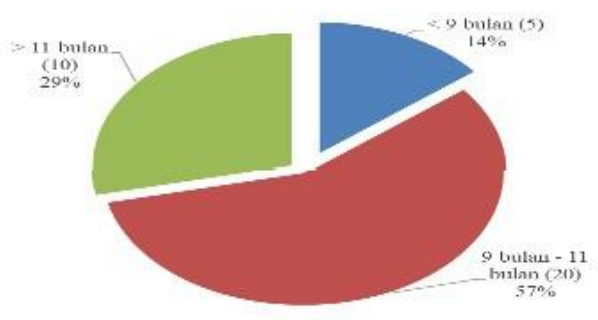


Berdasarkan diagram diatas, dari 35 responden terdapat 20 responden dengan anak usia 9 -II bulan (57\%), 10 responden dengan anak usia > II bulan (29\%), dan 5 responden dengan anak berusia $<9$ bulan (14\%). Hal ini menunjukanbahwa mayoritas responden yang datang ke posyandu dengan anak berusia 9 - II bulan.

\section{Karakteristik Responden Berdasarkan Pekerjaan}

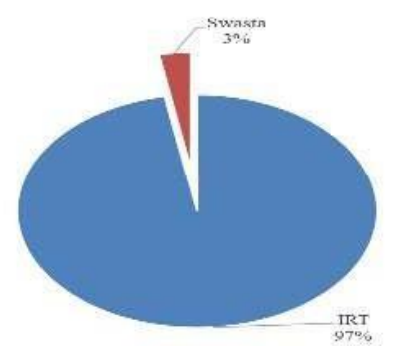

Berdasarkan diagram diatas, dari 35 responden terdapat I responden dengan pekerjaan swasta (3\%), 34 responden dengan pekerjaan IRT (97\%). Hal ini menunjukan bahwa mayoritas responden merupakan ibu rumah tangga (IRT).

Hasil identifikasi peran kader di Posyandu Wilayah Puskesmas Kereng Bangkirai Kota Palangka Raya

Tabel I. Peran Kader di Posyandu Wilayah Kerja Puskesmas Kereng Bangkirai Kota Palangka Raya

\begin{tabular}{lll} 
Peran & Frekuensi & Persen \\
\hline Baik & 2 I & 60.0 \\
\hline Cukup & 8 & 22.9 \\
\hline Kurang & 6 & 17,1 \\
\hline Total & 35 & 100
\end{tabular}

Berdasarkan tabel I diatas menunjukan bahwa dari total 35 responden mayoritas responden menyatakan peran kader baik yaitu sebanyak 21 orang $(60,0 \%)$, sedangkan yang menyatakan peran kader cukup sebanyak 8 orang responden (22,9\%), dan yang menyatakan peran kader kurang ada sebanyak 6 orang responden $(17,1 \%)$.

Hasil identifikasi cakupan imunisasi dasar lengkap di Posyandu Wilayah Puskesmas Kereng Bangkirai Kota Palangka Raya

Tabel 2. Cakupan Imunisasi Dasar Lengkap di Posyandu Wilayah Kerja Puskesmas Kereng Bangkirai Kota Palangka Raya

\begin{tabular}{lll} 
Imunisasi & Frekuensi & Persen \\
\hline Lengkap & 18 & 51.4 \\
\hline Belum & 13 & 37,2 \\
Lengkap & & \\
\hline Tidak & 4 & $1 \mathrm{I}, 4$ \\
Lengkap & & \\
\hline Total & 35 & 100
\end{tabular}

Berdasarkan tabel 2 menunjukan bahwa dari total 35 responden, terdapat sebanyak 18 responden memiliki anak dengan imunisasi dasar lengkap (5I,4\%), sedangkan sebanyak 13 responden memiliki anak dengan imunisasi belum lengkap (37,2\%), sedangkan sebanyak 4 responden memiliki anak dengan imunisasi tidak lengkap ( I I,4\%)

\section{Hasil analisis hubungan peran kader dengan cakupan imunisasi dasar lengkap pada bayi 0 - II bulan di Posyandu Wilayah Puskesmas Kereng Bangkirai Kota Palangka Raya}

Tabel 3. Analisis Berdasarkan Tabel Silang Hubungan Peran Kader dengan Cakupan Imunisasi Dasar 
Lengkap di Posyandu Wilayah Kerja Puskesmas

Kereng Bangkirai Kota Palangka Raya

\begin{tabular}{|c|c|c|c|c|c|c|c|c|c|}
\hline \multirow{3}{*}{$\begin{array}{l}\text { Peran } \\
\text { Kader }\end{array}$} & \multicolumn{6}{|c|}{ Imunisasi } & \multirow{2}{*}{\multicolumn{2}{|c|}{ Total }} & \multirow{3}{*}{$\begin{array}{l}\text { p- } \\
\text { value }\end{array}$} \\
\hline & \multicolumn{2}{|c|}{ Lengkap } & \multicolumn{2}{|c|}{$\begin{array}{l}\text { Belum } \\
\text { Lengkap }\end{array}$} & \multicolumn{2}{|c|}{$\begin{array}{c}\text { Tidak } \\
\text { Lengkap }\end{array}$} & & & \\
\hline & $\mathrm{N}$ & $\%$ & $\mathrm{~N}$ & $\%$ & $\mathrm{~N}$ & $\%$ & $\mathrm{~N}$ & $\%$ & \\
\hline Baik & 18 & $(51,4 \%)$ & 0 & $(0,0 \%)$ & 3 & $(8,6 \%)$ & 21 & $(60,0 \%)$ & \\
\hline Cukup & 0 & $(0,0 \%)$ & 7 & $(20,0 \%)$ & 1 & $(2,9 \%)$ & 8 & $(22,9 \%)$ & 0,003 \\
\hline Kurang & 0 & $(0,0 \%)$ & 6 & $(17,1 \%)$ & 0 & $(0,0 \%)$ & 6 & $(17,1 \%)$ & \\
\hline Total & 18 & $(51,4 \%)$ & 13 & $(37,1 \%)$ & 4 & $(11,4 \%)$ & 35 & $(100,0 \%)$ & \\
\hline
\end{tabular}

Berdasarkan tabel 3 diatas diketahui dari 35 responden terdapat sebanyak 21 responden menyatakan peran kader baik (60,0\%), terdapat sebanyak 8 responden menyatakan peran kader cukup $(22,9 \%)$ sedangkan sebanyak 6 responden menyatakan peran kader kurang (I7,I\%). Untuk cakupan imunisasi dasar lengkap dari 35 responden terdapat sebanyak 18 responden memiliki anak dengan cakupan imunisasi dasar lengkap (51,4\%), terdapat sebanyak 13 responden memiliki anak dengan cakupan imunisasi dasar belum lengkap (37,I\%), sedangkan sebanyak 4 responden memiliki dengan cakupan imunisasi dasar tidak lengkap $(1 \mathrm{I}, 4 \%)$. Berdasarkan hal tersebut diketahui juga bahwa peran kader baik $60 \%$ dengan cakupan imunisasi lengkap $5 \mathrm{I}, 4 \%$, peran kader cukup 22,9\% dengan cakupan imunisasi belum lengkap 37,1\%, sedangkan peran kader kurang 17,1\% dengan cakupan imunisasi belum lengkap II,4\%. Namun hal ini masih jauh dari target yang ditetapkan yaitu minimal $92 \%$ cakupan imunisasi dasar lengkap pada suatu wilayah.

Berdasarkan hasil analisis Chi-Square, untuk mengetahui peran kader dengan cakupan imunisasi dasar lengkap pada bayi usia 0-II bulan di Posyandu Wilayah Puskesmas Kereng Bangkirai Kota Palangka Raya, diperoleh nilai Chi-Square $=0,003<(\alpha=0,05)$, maka HO ditolak dan $\mathrm{HI}$ diterima, hal tersebut berarti terdapat hubungan yang bermakna antara peran kader dengan cakupan imunisasi dasar lengkap pada bayi usia 0-II bulan di Posyandu Wilayah Puskesmas Kereng Bangkirai Kota Palangka Raya.
Peran adalah suatu yang diharapkan dari seseorang dalam situasi sosial tertentu agar memenuhi harapan. Peran petugas kesehatan adalah suatu kegiatan yang diharapkan dari seorang petugas kesehatan yang memberikan pelayanan kesehatan kepada masyarakat untuk meningkatkan derajat kesehatan masyarakat (Ali, 2007:45).

Kader adalah seorang tenaga sukarela yang direkrut dari, oleh dan untuk masyarakat, yang bertugas membantu kelancaran pelayanan kesehatan. Keberadaan kader sering dikaitkan dengan pelayanan rutin di Posyandu.

Sehingga seorang kader Posyandu harus mau bekerja secara sukarela dan ikhlas, mau dan sanggup melaksanakan kegiatan Posyandu, serta mau dan sanggup menggerakkan masyarakat untuk melaksanakan dan mengikuti kegiatan Posyandu (Ismawati dkk, 20l0:42).

Menurut penelitian yang dilakukan oleh Budiman (2016) mengatakan, bahwa kehadiran kader sebagai penggerak kegiatan dimasyarakat sangat berpengaruh terhadap peningkatan cakupan imunisasi pada bayi.

Kehadiran petugas memberikan motivasi yang tinggi pada masyarakat padaumumnya dan ibu-ibu balita pada khususnya, untuk datang ke pelayanan kesehatan. Kehadiran petugas juga akan meningkatkan daya tarik masyarakat untuk memeriksakan kesehatan dan juga ibu-ibu dapat mengimunisasikan bayinya. Kader Posyandu sangat penting peranannya dalam melakukan kunjungan rumah khususnya ibu yang mempunyai bayi dan balita untuk memberikan penyuluhan danmengingatkan mereka agar mau datang ke Posyandu. Hal ini terutama dalam upaya pemberian imunisasi yang paripurna pada seorang anak.

Hasil yang didapat bahwa peran kader Posyandu merupakan salah satu faktor penting dalam kegiatan imunisasi, dalam pelaksanaan kegiatan imunisasi peran kader diperlukan agar kegiatan dapat berjalan pada jadwal yang telah ditentukan ini dapat dilihat bahwa 
kader berperan aktif dalam kegiatan Posyandu, diantaranya mengingatkan kembali orang tua untuk datang kembali pada jadwal imunisasi berikutnya, memberikan motivasi kepada ibu untuk hadir dalam kegiatan Posyandu berikutnya, melakukan komunikasi dengan baik kepada orang tua saat pelaksanaan imunisasi.

Arti penting peran kader kesehatan sangat berpengaruh terhadap kelengkapan cakupan imunisasi dasar, yang berarti bahwa semakin baik peran kader kesehatan dalam memberikan informasi dan motivasi kepada masyarakat khususnya orang tua yang memiliki bayi untuk mendapatkan imunisasi maka dapat meningkatkan derajat kesehatan yang ada dimasyarakat. Sehingga pelayanan kesehatan yang selama ini dikerjakan oleh petugas kesehatan saja dapat dibantu oleh masyarakat khususnya kader dapat berjalan dengan baik. Dengan demikian masyarakat bukan hanya merupakan objek pembangunan, tetapi juga merupakan mitra pembangunan itu sendiri. Selanjutnya dengan adanya kader, maka pesan- pesan yang disampaikan dapat juga diterima oleh masyarakat, jelaslah bahwa pembentukan kader adalah perwujudan pembangunan dalam bidang kesehatan.

\section{KESIMPULAN}

Berdasarkan analisis dengan menggunakan uji statistik dengan metode chi square hasil 0,003 $<0,05$ berarti $\mathrm{HI}$ di terima menunjukan hubungan yang signifikan dan bermakna.

Berdasarkan hasil tersebut maka dapat disimpulkan bahwa adanya HubunganPeran Kader Dengan Cakupan Imunisasi Dasar Lengkap Pada Bayi Usia 0-II bulan di Posyandu Wilayah Kerja Puskesmas Kereng Bangkirai Kota Palangka Raya.

Hal tersebut dikarenakan kader kesehatan berperan penting dalam mengajak masyarakat khususnya orang tua yang memiliki anak untuk rutin datang ke Posyandu, melakukan kunjungan rumah, bagi bayi yang belum diimunisasi kader menganjurkan atau mendampingi orang tua untuk datang ke Posyandu memperoleh imunisasi, kader juga ikut menjawab rumor yang beredar dimasyarakat sehingga masyarakat tidak takut atau ragu membawa anaknya untuk diimunisasi, memotivasi orang tua untuk melakukan imunisasi dasar lengkap sesuai jadwal yang dilakukan dengan pendekatan secara persuasif karena kader merupakan pilihan masyarakat dan merupakan warga masyarakat disekitar wilayah tersebut.

\section{UCAPAN TERIMA KASIH}

Pada kesempatan ini peneliti menyampaikan ucapan terimakasih kepada :

I. Kepala Puskesmas Kereng Bangkirai Kota Palangka Raya yang telah memberikan ijin serta data-data yang diperlukan peneliti sebagai penunjang dari proses penelitian

2. Ketua STIKes Eka Harap yang telah memfasilitasi peneliti dalam proses penelitian

3. Para Responden yang bersedia meluangkan waktu untuk mengisi kuesioner penelitian

\section{REFERENSI}

I. Marimbi. Tumbuh Kembang, Status Gizi dan Imunisasi Dasar Pada Balita.Yogyakarta : Nuha Medika : 2014

2. Kemenkes RI (20I7). Profil Kesehatan RI, Jakarta

3. Kemenkes RI (2017). Pedoman Penyelenggaraan Imunisasi, Jakarta Kemenkes RI (20I3). Riset Kesehatan Dasar, Jakarta

4. Depkes RI. (2009). Perjalanan Menuju Indonesia Sehat 2010. Departemen Kesehatan RI, Jakarta.

5. Dinas Kesehatan Provinsi Kalimantan Tengah (2017). Laporan Tahunan Bidang Kesehatan Provinsi Kalimantan Tengah. Dinas Kesehatan Provinsi Kalimantan Tengah, Palangka Raya 
6. Puskesmas Kereng Bangkirai (2017). Profil Kesehatan Puskesmas KerengBangkirai

7. Kiftiyah (2017). Hubungan Peran Kader Dengan Cakupan Imunisasi Campak Pada Balita. Mojokerto : STIKES Dian Husada

8. Puskesmas Kereng Bangkirai (2018). Data Registrasi Ruang Kia Puskesmas Kereng Bangkirai Palangka Raya.

9. Budiman dan Agus Riyanto. (20/3). Kapita Selekta Kuesioner Pengetahuan dan Sikap dalam Penelitian. Jakarta: Salemba Medika. 